\section{ДОБЫЧА ЧОНАР-ДАША: ТРАДИЦИОННАЯ ТЕХНОЛОГИЯ И ЭЛЕМЕНТ ЭКОЛОГИЧЕСКОЙ КУЛЬТУРЫ ТУВИНЦЕВ}

THE EXTRACTION OF CHONAR-DASH: TRADITIONAL TECHNOLOGY AND A PART OF TUVAN ENVIRONMENTAL CULTURE

\section{Валерий О. Ооржак}

Тувинский институт комплексного освоения природных ресурсов Сибирского отделения Российской академии наук, Российская Федерация

В статье рассматриваются традиции добычи Чонар-Даш (агальматолита) в тувинской культуре, которые имеют свои особенности, в том числе направленные на сохранение месторождений и обеспечение их возобновляемости. Исследуются методы и способы добычи, а также воспитательное воздействие традиции по рациональному природопользованию, охране окружающей среды.

Чонар-Даш - «мягкий камень» - используется для создания изделий камнерезного искусства, древнего и популярного вида тувинского прикладного искусства. По убеждению мастеров-камнерезов, качество изделия напрямую зависит от того, в каких условиях этот камень «родился», то есть был добыт, с каким отношением к камню он был извлечен из-под недр земли.

Добыча производилась и до сих пор производится на горе Сарыг-Хая (Желтая Скала), расположенной на территории Бай-Тайгинского кожууна Республи-
Valery O. Oorzhak

Tuvan Institute for Complex Development of Natural Resources, Siberian Branch, Russian Academy of Sciences, Russian Federation

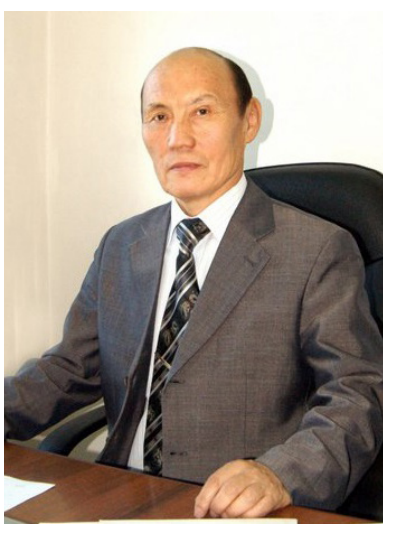

The article examines the traditions of excavating and extracting the ChonarDash (agalmatolite) in Tuvan culture - a process, including, inter alia, a concern for preserving the agalmatolite deposits and keeping them renewable. We have studied methods and ways of extracting the resource, as well as the educational impact of the tradition of environmental management and protection.

The Chonar-Dash, or 'soft stone', is used in the art of stone carving, which is an ancient and popular form of Tuvan applied art. Master stonecutters believe that the quality of the product directly depends on the conditions of the stone's 'birth', i.e. how it was extracted and what attitude to the stone the miners had.

The deposit used in the past and at present is the one on the Saryg-Haya (Yellow Rock) mountain located on the territory of the Bai-Taiga kozhuun of the Republic of Tyva. The process of extraction,

\footnotetext{
* Работа выполнена при поддержке РФФИ (проект «Обоснование стратегических направлений развития региона на базе исследования динамики модернизации социально-экономических процессов (на примере Республики Тыва)», грант № 18-410-170001)./ The study was supported by the RFBR (Grant No. 18-410-170001, Project title "Developing the strategic priorities of regional development on the basis of studying the dynamics of modernization of social and economic processes: the case of the Republic of Tuva").

Ооржак Валерий Окпан-оолович - кандидат экономических наук, старший научный сотрудник Тувинского института комплексного освоения природных ресурсов СО РАН. Адрес: 667007, Россия, г. Кызыл, ул. Интернациональная, д. 117а. Тел.: +7 (394-22) 662-77 доп. 13. Эл. адрес: v.oorgak@yandex.ru

Oorzhak Valeriy Okpan-oolovich, Candidate of Economics, Senior Researcher of Tuvinian Institute for Exploration of Natural Resources of Siberian Branch of the Russian Academy of Sciences. Postal address: 117a Internatsionalnaya St., Kyzyl, Russian Federation, 667007. Tel.: +7 (394-22) 662-77 extension number 13. E-mail: v.oorgak@yandex.ru
} 
ки Тыва. Подробно описан весь процесс добычи, начиная от обрядов. Сам процесс состоит из нескольких этапов: подготовительного, непосредственной добычи камня, отбора камней и возврата камней для сохранения обратно в яму, закрытие ямы. Описания сопровождают авторские схемы.

Особенно отмечается проблема современных разработок месторождения, в которых не соблюдаются правила сохранения месторождений. Это ведет к истощению запасов камней, растратам ресурсов, вызывает возмущение старых мастеров. Автор полагает, что правила обращения с окружающей природой тувинцев, которые демонстрирует данная технология, намного жестче требований современных экологических стандартов крупных промышленных предприятиях природопользования. Поэтому местным жителям сложно принять нововведения, проекты индустриализации. На этом противоречии базируются многие проблемы экономики республики.

Исследование основано на авторских полевых материалах с 1960-х гг. до 2018 г., на материалах из архива Национального музея Республики Тыва и др.

Ключевые слова: традиционная технология; добыча; экологическое воспитание; стратегия развития; Тува; Республика Тыва; экономическая культура; Чонар-Даш; агальматолит; региональная экономика starting with specific rituals, is described hete in detail. It includes several stages: preparatory; the extraction proper; the selection of stones; returning some of them into the pit for "saving"; and finally, the closure of the pit. The descriptions are illustrated by schemes, drawn by the author.

Ofhighest importance is the issue of contemporary mining without following these rules. This leads to the depletion of the deposit and a waste of resources, to which old masters react with a righteous anger. The author believes that the rules of engaging with the environment, as demonstrated by this old Tuvan technology, are a lot stricter than the modern environmental standards followed at large industrial enterprises dealing with nature. This is why it is difficult for local residents to accept innovations advanced by proponents of industrialization. These contradictions lie at the heart of many problems of the republic's economy.

The study has been based on the field materials collected by the author in 1960-2018, as well as those preserved at the National Museum of Republic of Tyva and other archives.

Keywords: traditional technology; extraction; environmental education; development strategy; Tuva; Republic of Tyva; economic culture; ChonarDash; agalmatolite; regional economy

\section{Введение}

В современных условиях индустриальных, технологических преобразований, социокультурных трансформаций традиционных обществ и наличия экологических проблем, исследования по проблемам обеспечения экологичного и эффективного природопользования с применением традиционных технологий приобретают особую актуальность. В том числе эта проблема важна и для Республики Тыва, в которой также остро стоит вопрос об адаптации этнокультурных практик с задачами экономического развития.

Традиционным технологиям переработки продукции живодноводства, земледелия, технологиям изготовления национальной одежды, мужских и женских украшений, изделий народных художественных промыслов, камнерезного, ювелирного искусства, историям их развития в Туве и т. д. уделено достаточно внимания исследователями (см.: Эренчин и др., 2018; Ооржак, Сайбу, 2013; Ондар, Бадыргы, 2015; Монгуш, 2017; Ондар, 2017; Ооржак, Ондар, 2012 и др.).

В то же время, по нашему мнению, малоизученными остаются особенности традиционных технологий добычи и использования природных ресурсов 
и минерального сырья, направленные на сохранение месторождений и обеспечение возобновляемости используемых ресурсов и экологии. Одной из таких технологий, имеющих особое значение для традиционной культуры тувинцев, является технология добычи агальматолита (от греч. agálmatosукрашение, статуя и líthos- камень), горного породообразующего минерала. Это плотная мелкозернистая метаморфическая горная порода, состоящая преимущественно из минерала пирофиллита, обычно с примесью талька, слюдистых и глинистых минералов. Синонимы: пагодит, восковой камень, жировик (жировиком и восковым камнем, часто называют также мыльный камень); в древности на территории Китая, Кореи, Японии, Монголии и Бурятии этот камень называли «фудзянским жадом» и из него изготавливали печати, украшения и предметы обихода. На тувинском языке он называется Чонар-Даш («мягкий камень») и используется камнерезами для изготовления поделок, статуэток, оберегов и пр. Агальматолит добывают на Урале, Алтае, в Бурятии, в Юго-Восточной Азии, Монголии, Узбекистане, Чехии, Румынии. В России камнерезное искусство приобрело особый национальный колорит прежде всего в Туве и Бурятии. И как пишут исследователи, резьбой по камню Чонар-Даш тувинцы занимались издревле (Вайнштейн, 1974; Будегечи, 1995).

Целью данной работы является исследование особенностей традиционной технологии добычи Чонар-Даша, методов и способов обеспечивающих сохранение и возобновление месторождения, ее специфику воспитательного воздействия по рациональному природопользованию, охране окружающей среды, и роли в экономической культуре тувинцев. Наряду с обсуждением особенностей экономической культуры тувинцев в настоящее время данная тема является очень важной и в связи с поиском возможностей эффективного участия местных жителей в экономическом развитии региона согласно задачам Стратегии социально-экономического развития Республики Тыва до 2030 года.

Подобное исследование требует применения междисциплинарного подхода, причем учитывающего результаты и методы социальных и естественных наук. Источниковой базой для нас выступили авторские полевые материалы, собранные во время выездов:

- в 1965-1972 гг. и 1975-1985 гг. с мастерами-камнерезами в Бай-Тайгинский и Барун-Хемчикский районы (где находятся месторождения агальматолита);

- в 1986-1991 гг. совместно со специалистами министерства культуры и министерства местной промышленности Тувинской АССР, экспериментального предприятия народных художественных промыслов и сувениров, так же и совместно с специалистами и учеными из Москвы (из НИИ МинМестПрома РСФСР);

- в 1985, 1988, 1996 и 1998 гг. с мастерами-камнерезами в Чеди-Холский район с целью изучения возможностей кожууна по созданию участка надомного 
труда (филиала) экспериментального предприятия народных художественных промыслов и сувениров (ЭП НХПиС) с камнерезным цехом, Минместпрома Тувинской АССР и изучения экологических проблем ГОК «Тувакобальт»;

- в 1999 г., 2005-2007 гг. в Каа-Хемский район с той же целью создания участка надомного труда (филиала) экспериментального предприятия народных художественных промыслов и сувениров (ЭП НХПиС) Минместпрома Тувинской АССР, а в последние годы и по изучения экологических проблем золотодобывающего предприятия «Тардан-Голд»;

- в 1985-1990 и 2016-2018 гг. в Эрзинский и Улуг-Хемские районы тоже с целью создания участка(филиала) экспериментального предприятия народных художественных промыслов и сувениров (ЭП НХПиС) Минместпрома Тувинской АССР (в Улуг-Хемском районе еще строилась фабрика народных художественных промыслов и сувениров).

Также источниками нашего исследования стали материалы из архива Национального музея Республики Тыва; рассказы-вспоминания старых народных мастеров-камнерезов, которые автору пришлось слушать в 1960-1970-х годах в качестве ученика в камнерезном кружке от М.-Д. С. Хертека (1915-1973), Х. К. Тойбухаа (1917-1981), К. М. Саая (1931 г. р.).

Автор опирался на работы ученых Сибирского отделения РАН и Тувинского института комплексного освоения природных ресурсов Сибирского отделения РАН по проблемам адаптации коренных жителей Тувы к рынку труда в современных условиях, определения потенциала природных минеральносырьевых ресурсов региона, разработки концепций и Стратегий развития республики и др. Публикаций непосредственно по нашей тематике вышло не много, в том числе и авторских (Оюн, 2012; Кухта, Ооржак, 2014; Ооржак, 2015).

\section{Правильный настрой и нужный сезон}

В любой традиционной культуре заложены традиции разумного отношения к окружающей природе, поскольку это связано с задачами адаптации хозяйственной деятельности человека. В том числе и тувинская культура отличается экологичностью, что отражено и в общем мировоззрении культуры, и во всех ее аспектах. Бережное природопользование тувинцев мы наблюдаем и в таком виде деятельности как способы, методы (технологии) добычи поделочного камня Чонар-Даш, которые, к сожалению, забываются и уходят в прошлое.

Сама же проблема встает острее, особенно в связи с тем, что сегодня резьбой по камню в Туве занимается все большее количество людей, поскольку такие изделия востребованны. Подобные мастера насыщают рынок, вносят определенный вклад в социально-экономическое развитие региона, но в то же время их деятельность поднимает вопросы обеспечения их сырьем и 
сохранности ограниченных запасов камня Чонар-Даш. И проблемы эти, на наш взгляд, даже важнее,чем даже задачи стилистическойпреемственности в тувинскомкамнерезном искусстве, связанные с сохранением традиций (Кореняко, 2002).

Тувинский Чонар-Даш - буквально «камень, который можно резать» - легко поддается обработке стальными инструментами, не крошится, шлифуется и полируется наждачной бумагой, обладает эластичностью и достаточно легко превращается в пластичную, мягкую форму с плавными контурами, которую придает ему рука мастера (Кухта, Ооржак, 2014). Специфика технологии художественной обработки камня определяется его физическими

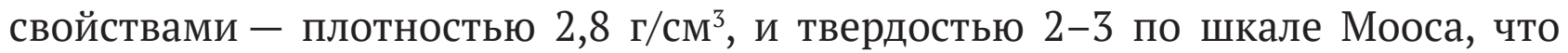
относит агальматолит к мягким породам.

Тувинская специфика резьбы по камню относится искусствоведами, в основном, к скифскому звериному стилю. Важной особенностью в нем является смелое нарушение пропорций тела животного, когда декоративная скульптура подчинена принципу силуэтного решения, что помогает ее выразительности и ясному восприятию даже в очень малых размерах. Этому же способствует традиционный прием обработки поверхности камня: сопоставление гладких поверхностей объема с деталями, проработанными укрупненной резкой, доведенной до выраженной орнаментации. Характерными стилистическими особенностями тувинского камнерезного искусства является так же и проявляющиеся сочетания реализма с декоративной стилизацией образов.

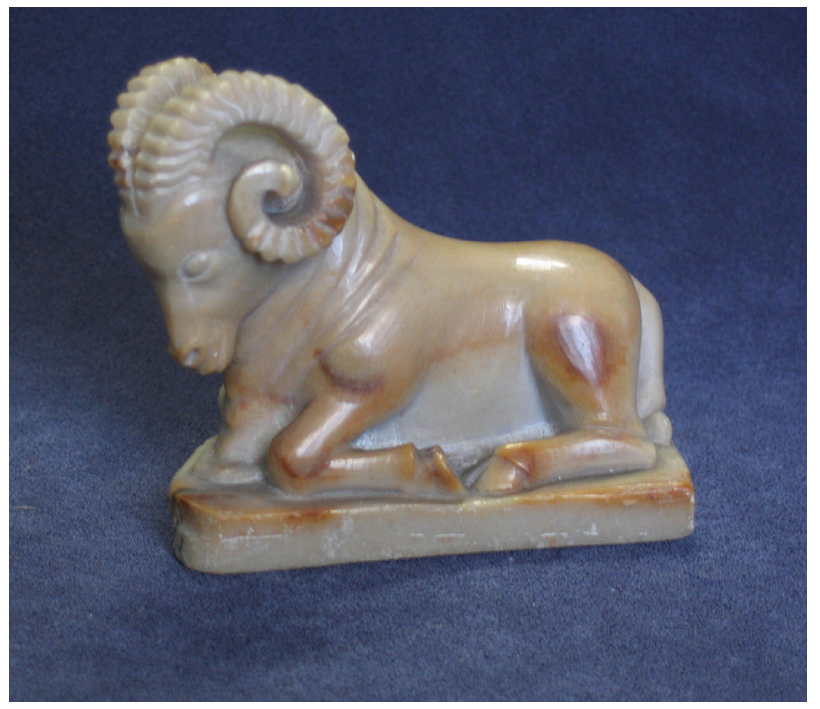

Фото 1. «Кошкар». Работа Х. К. Тойбухаа (1955). Размеры: 12х8х6. Из архива Национального музея им. Алдан-Маадыр РТ, г. Кызыл.

Photo 1. "Koshkar", by H.K. Toibuhaa (1955), dimensions $12 \times 8 \times 6$. From the archives of AldanMaadyr National Museum of Tuva, Kyzyl.

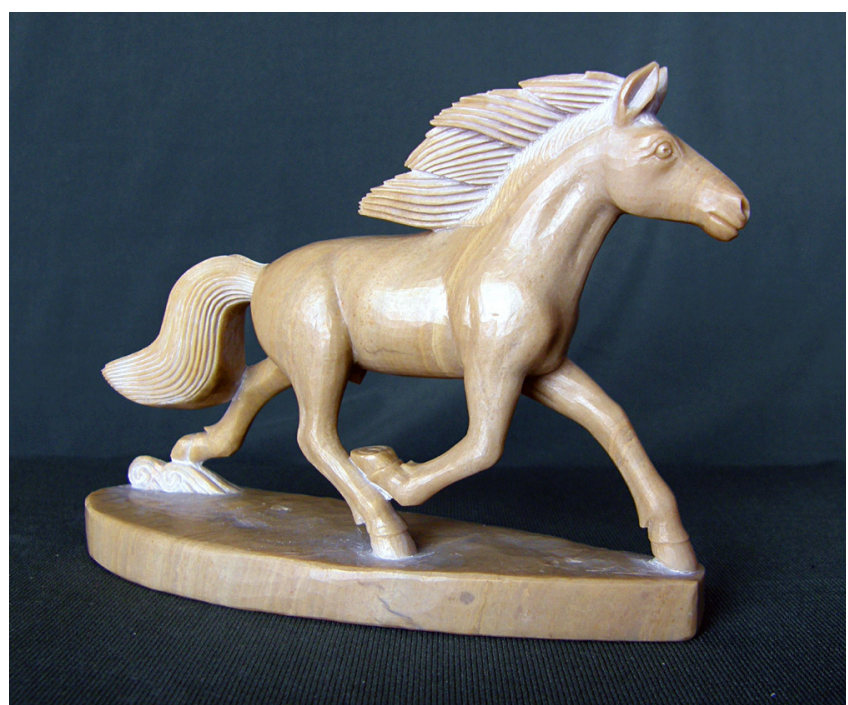

Фото 2. «Конь». Работа В. О. Ооржак (2003). Размеры:14х10х4. Из архива Национального музея им. Алдан-Маадыр РТ, г. Кызыл.

Photo 2. "The Horse”, by V.O. Oorzhak (2003), dimensions 14x10x4. From the archives of Aldan-Maadyr National Museum of Tuva, Kyzyl. 
Для камнерезного искусства Тувы, сложившегося в условиях кочевого быта, характерными являются изображения животных - верблюдов, баранов, коней, отдыхающих, играющих со своими детенышами, или выступающих героями сюжетных композиций. На фото 1 u 2 представлены работы Х. К. Тойбухаа и В. О. Ооржак, выполненные в стиле традиционного камнерезного искусства Тувы.

Народные мастера по камнерезному искусству говорили, что качество изделия из камня Чонар-Даш напрямую зависит от того, в каких условиях этот камень «родился», то есть был добыт, с каким отношением к камню он был извлечен из-под земли. От того, был ли добытчик в благих намерениях зависело, какими получатся работы из камня. Считалось,что для изготовления по настоящему изящных и тонких фигур необходимо относиться к Чонар-Дашу как к живому с первых же моментов приближения к нему. Поэтому сама добыча расценивалась как священнодействие (Демин и др., 1969; Червонная, 1995).

В прежние годы и в настоящее время добыча агальматолита в Туве производились и производятся только на горе Сарыг-Хая (Желтая Скала), расположенной на территории Бай-Тайгинского кожууна Республики Тыва. Но есть сведения, что проявления агальматолита выявлены в местечке Терлиг-Хая Кызылского кожууна (Лебедев, 2012), см. рисунок 1.

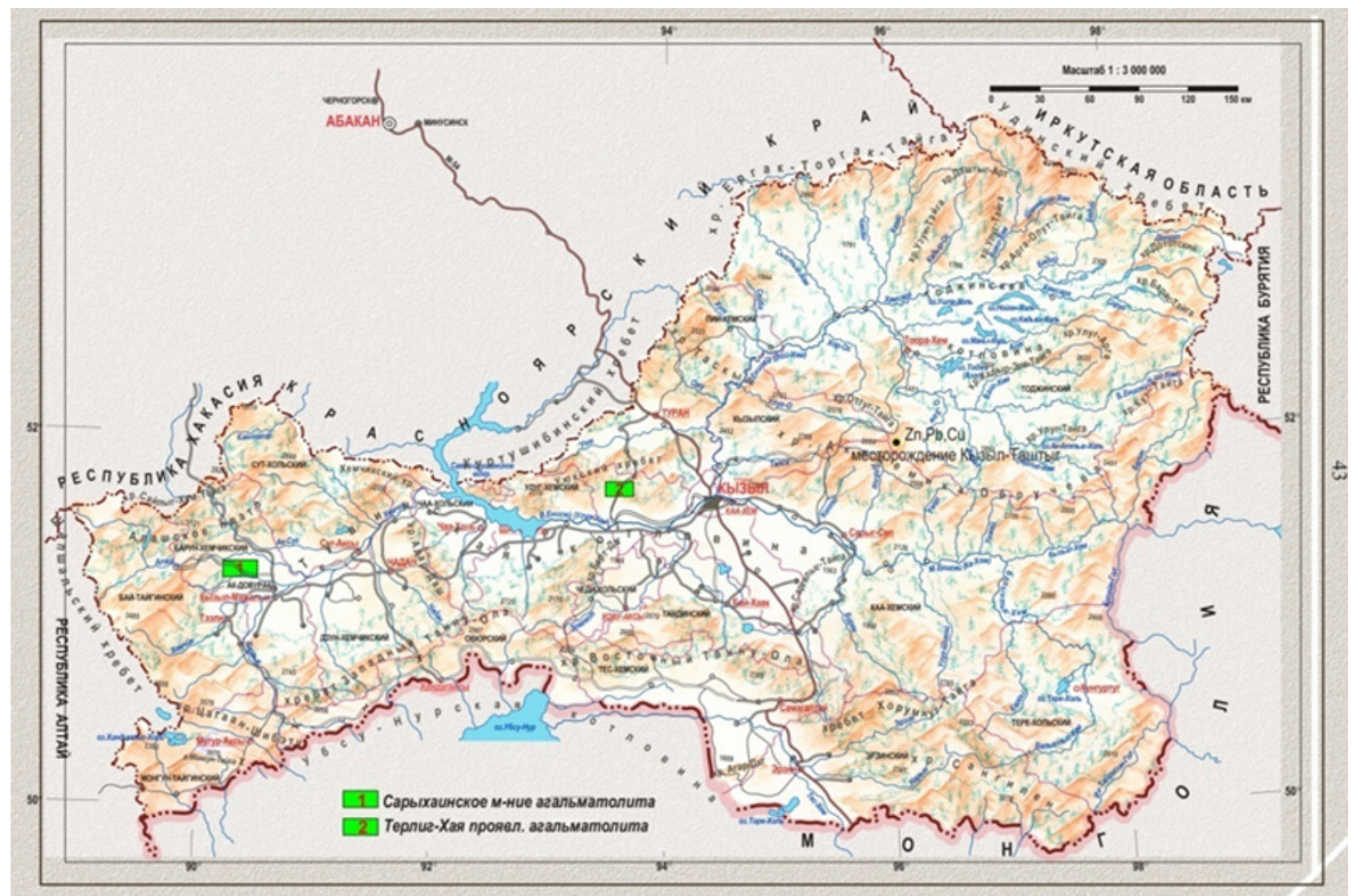

Рис. 1. Карта Тувы с месторождениями агальматолита.

Fig.1 The map of Tuva with deposits of agalmatolite marked. 


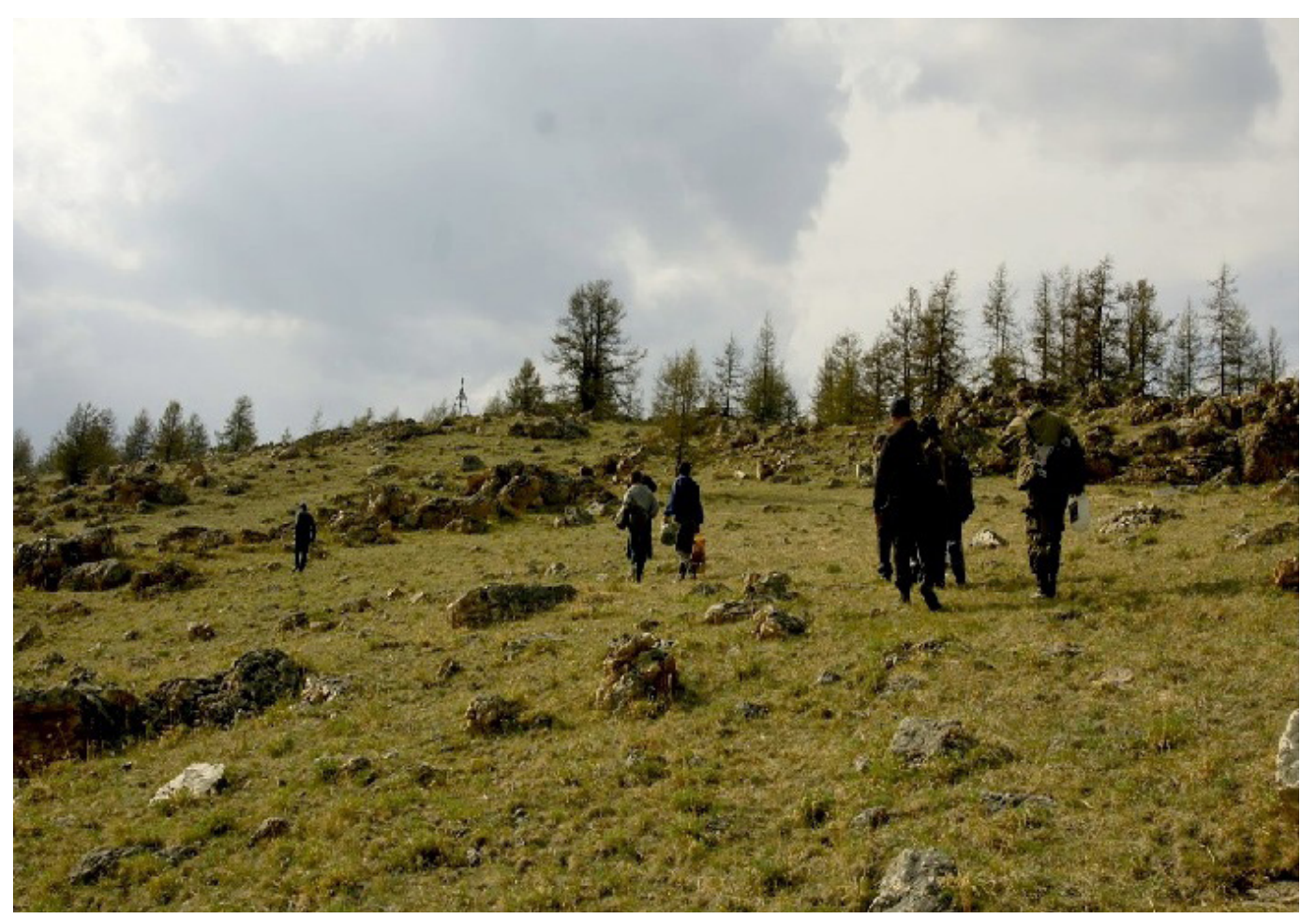

Фото 3. Вершина горы Сарыг-Хая, на которой находится месторождение Чонар-Даш. Из архива Национального музея им. Алдан-Маадыр РТ, г. Кызыл. 2005 г. Photo 3. The top of Mt. Saryg-Haya where the deposit of Chonar-Dash is located. From the archives of Aldan-Maadyr National Museum of Tuva, Kyzyl, 2005.

Прежде чем поехать за камнем, мастера тщательно готовились к предстоявшему процессу получения (изъятия) малой части «драгоценных» камней у святой горы. Готовили не только и не столько инструменты, одежду, лошадей или других вьючных животных и т. д. , сколько готовились духовно, моральнопсихологически. Каждый, кто едет добывать Чонар-Даш, должен был осознать важность этого события, определиться, для чего и сколько камня он хочет добыть, соизмерять свои желания с потребностями окружающих, а ожидаемые результаты (пользу) с неизбежностью наносимым природе ущербом (см.: Ооржак, 2015).

Добычу производили, как правило, поздней осенью или в начале зимы, когда верхний слой земли промерзал примерно на глубину не менее 20-40 cм (бир-ийи карыш - в одну-две пяди, т. е. в одну-два расстояния между концами раз-двинутых пальцев рук - среднего и большого).

В настоящее время у наших современников, даже из числа мастеров-камнерезов возникает множество вопросов по сезону: почему именно осенью, почему именно тогда когда земля замерзнет, зачем лишний труд, для чего дополнительные экономически нецелесообразные затраты и т. д.

Причины появления такой традиции достаточно серьезные. Замерзший верхний слой земли давал возможность сохранить при раскопке глубинных 216 
уургай (расширяющихся по глубине, кувшинообразных ям-шурфов) большую часть поверхности - растительного слоя земли. Конечно, при этом появлялась необходимость проведения дополнительной работы по обжигу (оттаиванию) верхнего замерзшего слоя земли, возникала сложность работы в глубокой яме с выниманием пород через относительно небольшое верхнее отверстие, обратная их укладка через это же отверстие. Но этот способ давал возможность сохранить верхний слой земли, который мог обрушиться при раскопках. А главное - это обеспечивало сохранение природных запасов минералов для будущих раскопок.

Благодаря соблюдению многовековых традиций в технологии добычи Чонар-Даша, нашим предкам удавалось сохранить месторождение почти в первозданном виде (фото 3).

Еще в начале 1970-х гг., когда автор впервые начал участвовать в раскопках по добыче Чонар-Даша, месторождение на горе Сарыг-Хая не смотря на его длительную (более 500 лет) эксплуатацию, было настолько умело и хорошо сохранено, что на нем почти не было видно следов предыдущих раскопок.

\section{Сакральные правила}

В 1970 году один из старейших народных мастеров-камнерезов Бай-Тайги, Хертек Сегбе-оглу Мижит-Доржу согласился взять с собой нас, подростковшкольников в поездку за камнем Чонар-Даш и обещал показать все: когда, где, как надо его добывать.

В первую очередь, еще весной он раздал нам куски (обрезки от своих) самых мягких, светлых камней и предложил за время летних каникул вырезать из них кто что сможет. Изделия следовало показать ему для определения того кто, на что способен и кому сколько, какие камни нужны. Мы все старались, по его совету вырезали разные фигуры, даже шахматные, показывали ему как на экзамене. К концу лета из дюжины ребят осталось нас четверо. Но поездка затягивалась. И на каждый наш вопрос «Когда поедем?», ответ был короткий: «Уези келбээн, элек» («Время не пришло, рано еще»).

Наконец в начале октября мастер сообщил нам: «Уези келген дир» («Время наступило»). Выехать следовало очень рано, до зари. На высоких горах уже лежал снег. Когда мы поднялись на гору Сарыг-Хая и добрались до месторождения, снег растаял. По прибытию на место Мижит-Доржу совершил обряды, мы помогали ему.

Обряды получения разрешения у хозяина священной горы Сарыг-Хая и у хозяина Великой Бай-Тайги (Богатой-Тайги) на раскопку (добычу) камня ЧонарДаш состояли из следующих действий. Каждый доставал из своей наплечной сумки (рюкзака, сумки, или таалын - вьючных мешков-корзинок для лошадей) 
заранее заготовленные дары для месторождения (небольшое количество зерна пшеницы или ржи, а также молоко в емкостях) и передавал старшему. Привезенные с собой кадак (небольшие полоски шелковой ткани белых и светлых тонов) сами привязывали на ветки священного дерева, обращаясь к тайге с молитвой-просьбой разрешения начать земляные работы по добыче камней. В то же время старший группы, произнося молитвы, разбрасывал по территории месторождения переданные ему дары. Затем разводили небольшой общий костер, и, обращаясь к хозяевам огня, тайги и земли с молитвойпросьбой, старший группы предавал огню кусочки продуктов, топленого масла, сыпал муку, брызгал молоко.

Когда костер догорал, в молитвенном молчании ждали появления небесного знака разрешения или не разрешения. Если небо оставалось ясным и на вершинах священной, великой Бай-Тайги которая хорошо видно с вершины горы Сарыг-Хая, не появлялись туман или облако, то это расценивалось как благоприятный знак. Туман, облако или ухудшение погоды означали, что землю копать нельзя, только можно выбрать камни, лежащие на земле (оставшиеся возле предыдущих копей). А в случае снегопада или сильной бури, считалось, что и копать нельзя, и камни нельзя брать (см.: Ооржак, 2015).

Последующие этапы мы изложим в соответствии с тем, как это делается в подобных случаях, описанных нами в предыдущей публикации (см.: там же).

Перед началом работы старший группы проводит беседу-инструктаж, объясняя, где и как начинать копать землю, какие инструменты и в какой последовательности использовать, и какими способами работать, как производить выемку грунта и камней.

Сам процесс традиционной технологии добычи Чонар-Даша состоит из нескольких этапов: подготовительного, непосредственной добычи камня, отбора камней и возврата камней для сохранения обратно в яму, закрытие ямы.

Подготовительные работы. Производится выбор участка земли и его проверка напредмет отсутствия посторонних предметов и обстоятельств, которые могут не позволить проведение земляных работ: наличие признаков проведения недавних раскопок, наличие молодых порослей деревьев, крупных корней близрастущих деревьев, наличие крупных (огромных) камней или скал, видных из под земли и т. д. Далее идет подготовка площадки перед раскопками - очистка от лишних предметов.

Напредварительно выбранном и подготовленном участке земли делают отметку в виде круга для последующей укладки дров и разведениякостра для оттаивания замерзшего верхнего слоя земли. В зависимости от количества участников раскопки и предполагаемого объема добычи камня Чонар-Даш, размер кругаможет варьировать от 80 см до 1,5 м. Под ним должен и копаться уургай - шурф. 
Вокруг намеченного круга помечают еще один круг, в которомдолжны укладываться камни и грунт для защитной от огня полосы (камгалал - оттан (оон изиинден) камгалаар чал) шириной около полметра высотой 20-40 см. Данная полоса-преграда предназначена для защиты верхнего слоя земли вокруг костра от высокой температуры и сохранения в замерзшем состоянии. Следующими более большими диаметрами отмечают круги-участки, где должны укладываться вынутые из-под земли грунты, камни, горные породы и Чонар-Даш. При этом должен соблюдаться порядок укладки: грунты верхнего слоя размещаются наиболее отдаленно от ямы, а вынутые из глубины - поближе к яме, для облегчения последующей обратной укладки в яму камней и грунта.

Примерная схема планировки размещения грунтов и камней при традиционных технологиях добычи Чонар-Даша показана на рисунке 2.

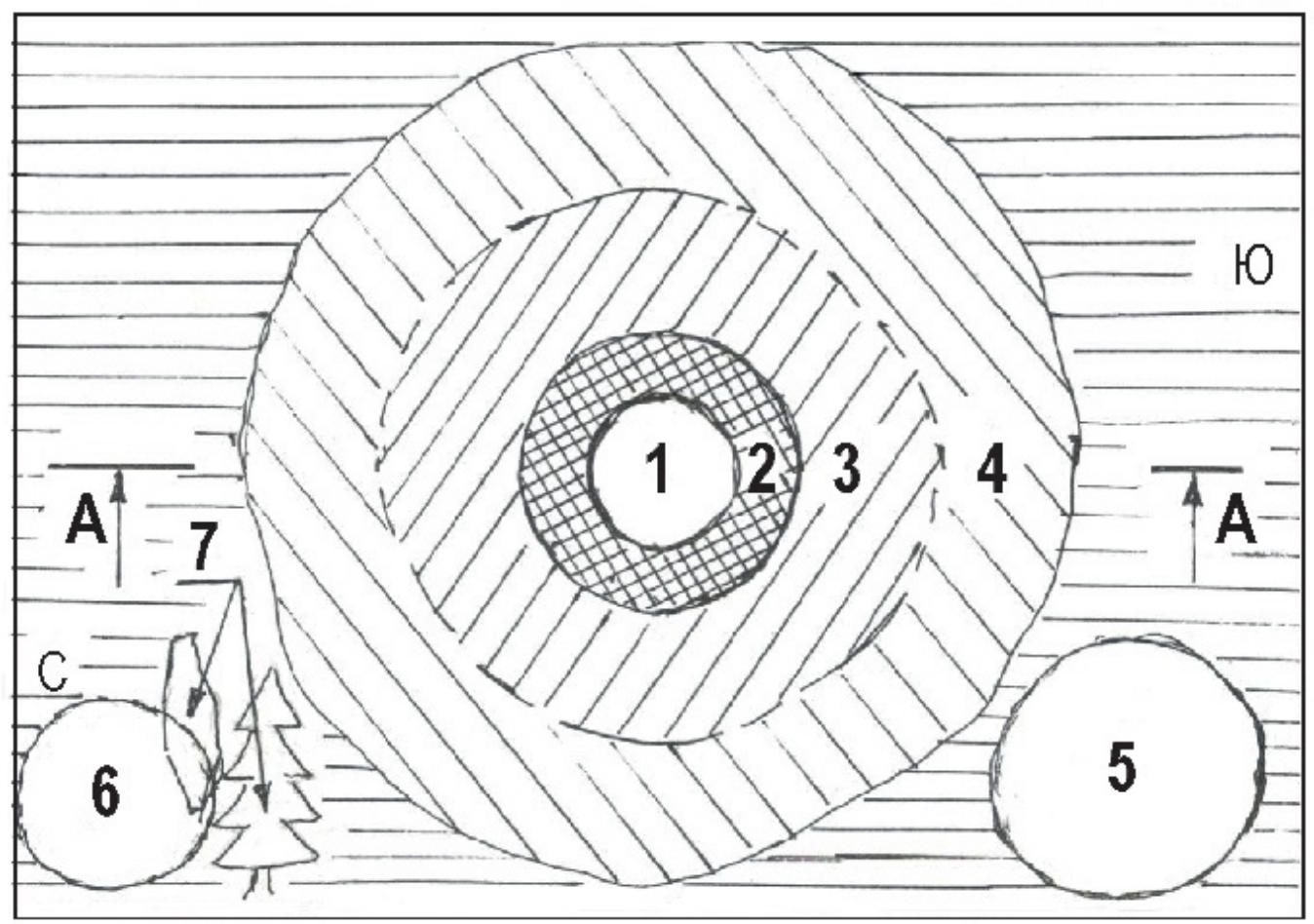

Рис 2. Схема размещения грунтов и камней при традиционных технологиях добычи Чонар-Даша. Составлена автором.

Fig. 2. The deployment of soil and stones in the traditional technology of Chonar-Dash excavation. Made by the author.

Прим.: 1 - круг - место предполагаемого костра для оттаивания замерзшего верхнего слоя грунта; 2 - место устройства защитной полосы вокруг костра; 3 - участок земли, где должны складировать вынутые с глубин ямы-шурфа чистые горные породы и камни агальматолита; 4 - место складирования грунтов и камней вынутых из верхних слоев ямы-шурфа; 5 - место укладки-складирования грунтов верхнего растительного слоя земли; 6-место укладки отобранных камней агальматолита - Чонар-Даш; 7 - дерево или скала-камень, в тени которого должны складироваться отобранные агальматолиты Чонар-Даш; С - север; Ю - юг; А-А - разрез по вертикали. 
Непосредственные раскопки земли для добычи Чонар-Даша. Начинали работы с подготовки устройства защитной полосы вокруг заранее отмеченного места разведения костра. Для этого стаскивали камни, грунт и аккуратно укладывали на отмеченном круге в достаточном объеме и величины (толщины и ширины), чтобы обеспечить защиту от огня замерзший грунт. Затем собирали дрова и разводили костер внутри защитной полосы. Костер должен был быть достаточной мощности и длительности, чтобы оттаял замёрзший грунт во внутренних пределах защитной полосы.

После оттаивания верхнего замерзшего слоя земли, аккуратно удаляли оставшиеся остатки дров и золы, так же камни и грунт защитной полосы. При этом, вынутый из верхних оттаявших (растительных) слоев земли грунт аккуратно укладывали отдельно, подальше от копаемой ямы, на заранее подготовленную площадку 5 (см. рисунок 2). Для перемещения грунтов и камней использовались «волокушки», изготовленные из шкур домашних животных.

Следующую часть вынутых из ямы грунтов, горных пород и камней укладывали уже вокруг ямы, на заранее отмеченные места (в третьем от ямы круге - под номером 4 на рисунке 2), строго соблюдая порядок укладки по сторонам света. Другими словами, все, что было вынуто из северной стороны ямы-шурфа, укладывали на земле тоже на северной стороне ямы, а все, что было вынуто из глубин западной стороны ямы, также на земле с западной стороны ямы и т. д.

По мере углубления раскопок параллельно шло и расширение диаметра ямы-шурфа в целях охвата большего объема добываемого камня. При этом обязательно должен соблюдаться принцип - уургай или кудук хевири «колодцеобразность» или «шурфообразность». Обычно, по ходу копания, ниже растительного слоя попадаются и вынимаются грунты и камни, состоящие в основном из разных горных пород (суглинка, песка и других примесей). Примерно по достижению глубины более метра начинают попадаться уже пригодные для обработки и использования камни Чонар-Даш. Когда попадались хорошие камни, все они укладывалисьна другую площадку, ближе к яме во вторую окружность, также с соблюдением принципа сторон света и места выема.

По достижению глубины более 1,5-2 м начинались участки, где находятся чистые отложения массива камней агальматолита. Здесь открывается красивейшая картина - как будто специально уложенные аккуратные ряды «волшебного камня». Бывают они разных размеров, по большей части правильной прямоугольной формы, промытые до блеска грунтовыми водами, влажные, без содержания каких либо других камней и примесей. В поисках Чонар-Даша нужных габаритов и размеров все камни из глубины ямы вынимаются наверх и укладываются уже поближе к яме, с тем же строгим соблюдением сторон света и порядка последовательности выема камней. 
Камни должны выниматься со дня ямы, а не из боковых стен во избежание обвала верхних слоев грунта земли.

Отбор камней Чонар-Даш. Проверка качества пригодности и отбор камней Чонар-Даш производилась по размерам, конфигурациям, оттенкам цвета и первичной твердости (фото 4) - методом визуального обзора и контроля на ощупь и запах. Важным было соответствие камней заранее продуманным сюжетам, композициям.

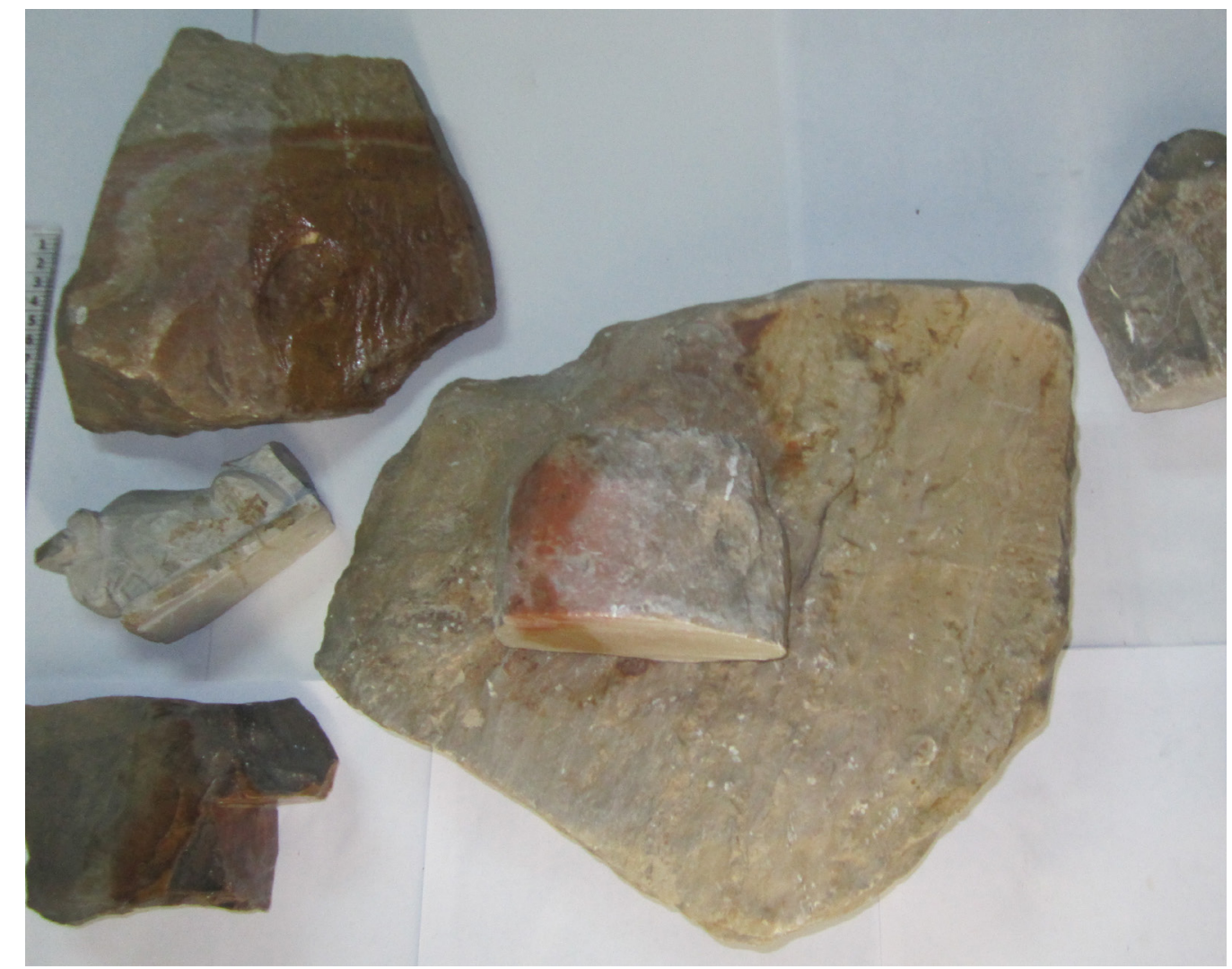

Фото 4. Разные виды камней Чонар-Даш. Фото автора, 2018 2.

Photo 4. Various types of Chonar-Dash stones. Photo by the author, 2018.

Те камни, которые наиболее соответствовали необходимым параметрам, откладывали. Затем они проверялись на качество с помощью инструмента специально заготовленного и хорошо заточенного «первого» большого ножадля первичной (грубой) обработки камня (баштайгы кылын чонуушкуннар кылыр). Им делалась пробная резьба по разным сторонам камня. Проверка твердости камня производилась иногда по всей ширине камня. Параллельно надо было очень внимательно следить за ходом движения ножа, не цепляется ли лезвие за трещины или за инородные тела, для определения внутри структуры камня других отложений (особенно твердых алмазоподобных образований), которые могут повредить лезвие ножа и стать причиной невозможности создания тончайших манипуляций. Далее идет проверка на наличие трещин и сколов - 
для этого проводят острым ножом поперечные резания по всей ширине камня, хорошо их очищают, и намочив водой, внимательно смотрят, стараясь увидеть даже микротрещины.

При необходимости проверку и отбор камня проводят и с помощью кержек специального остроконечного молотка, аналога современной маленькой кирки (кайлы) и специально изготовленной и закаленной для пиления камня пилы. Опытные камнерезы, простукивая Чонар-Даш кержеком, могут определить также внутренние, невидимые дефекты камня. Иногда распиливают камень в целях определения качества изнутри и внимательно изучают место распила.

Отобранные камни Чонар-Даш откладывают на отдельную площадку.

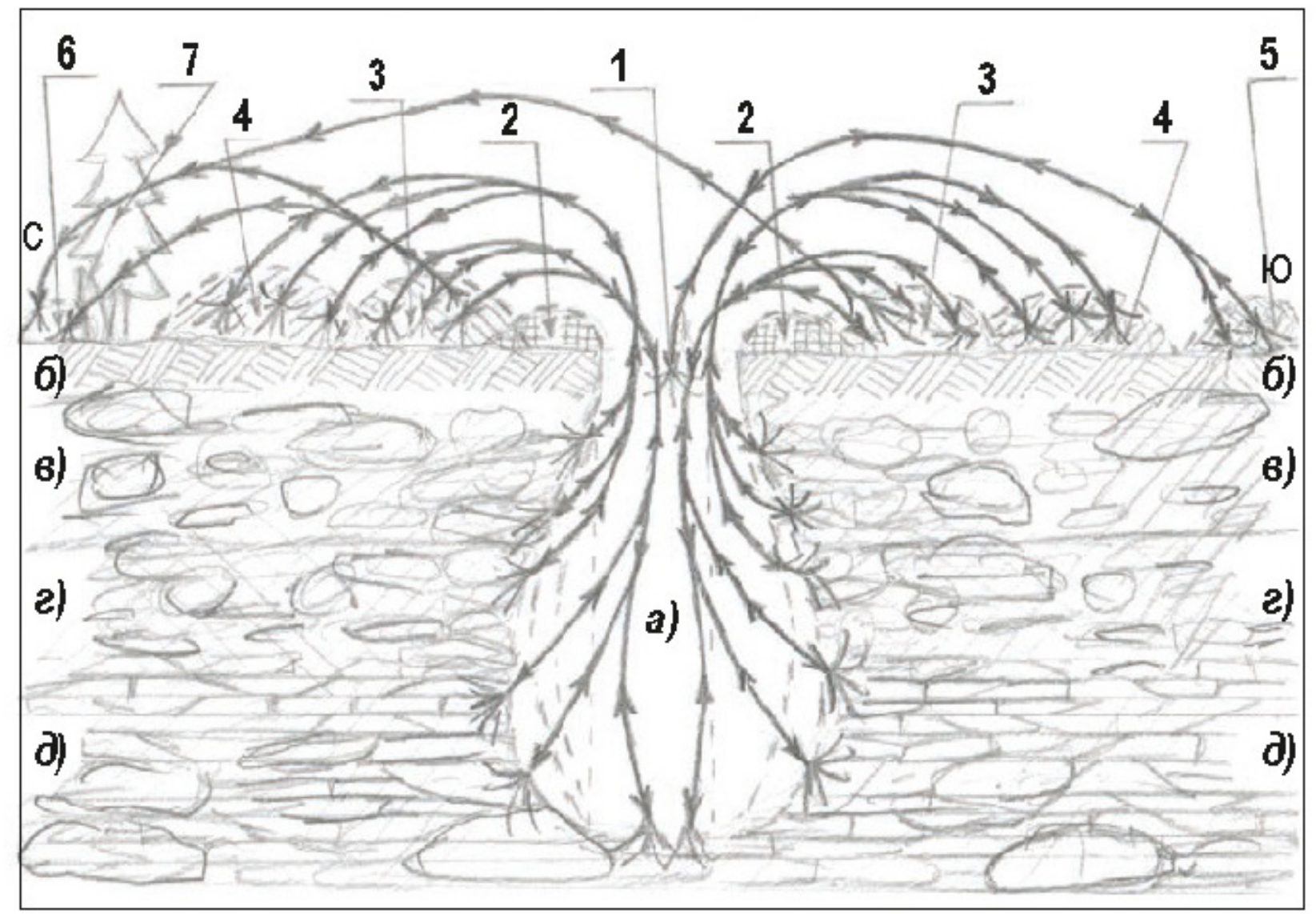

Рисунок 3. Разрез A-А. Схема перемещения грунтов и камней при традиционных технологиях добычи Чонар-Даша. Стрелками обозначен порядок перемещения грунтов и камней в соответствии с традиционными правилами эгидип-шыгжаар. Составлено автором.

Fig.3 A-A cross-section. The order of removing soil and stones in accordance with traditional technology of excavating Chonar-Dash; arrows indicate the procedure of moving soil and stones by the traditional rule of egidip-shygzhaar. Made by the author.

Прим.: Условные обозначения 1-7 см. в примечании к рис. 2. Далее: а) - зона предполагаемой раскопки шурфа для добычи камня Чонар-Даш; б) верхний (растительный) замерзший слой грунта земли; в) грунт верхних слоев горной породы; г) грунт средних слоев, где горные породы расположены вперемешку с агальматолитом; д) грунт с предполагаемым наличием агальматолита - Чонар-Даша. 
Возврат камней Чонар-Даш для сохранения. После того как будет отобрано задуманное количество Чонар-Даша, начинается последующий ответственный процесс эгидип-шыгжаары (возврат для сохранения) - процесс возврата оставшихся камней Чонар-Даш, горных пород и грунтов обратно в яму.

В первую очередь возвращают в яму и аккуратно укладывают камни ЧонарДаша, поднятые из глубины последними, строго соблюдая принцип стороны света, и в том же порядке и виде в каком они лежали до раскопки и их поднятия. То есть камни, поднятые с глубины, с южной стороны ямы должны быть возвращены строго туда, в южную часть глубины ямы, где лежали, а те, которые были взяты с середины ямы - в середину, и в строгой обратной последовательности.

По мере завершения обратной укладки камней Чонар-Даша, точно также аккуратно обратно укладываются просто камни, горные породы, песок и грунт. Последним производится обратная засыпка самого верхнего слоя растительного слоя, тоже соблюдением всех правил (рисунок 3).

При строгом соблюдении установленного порядка, яма должна быть почти полностью заполнена. После грамотной добычи камня Чонар-Даш месторождение должно иметь тот же вид, который имел до начала раскопок.

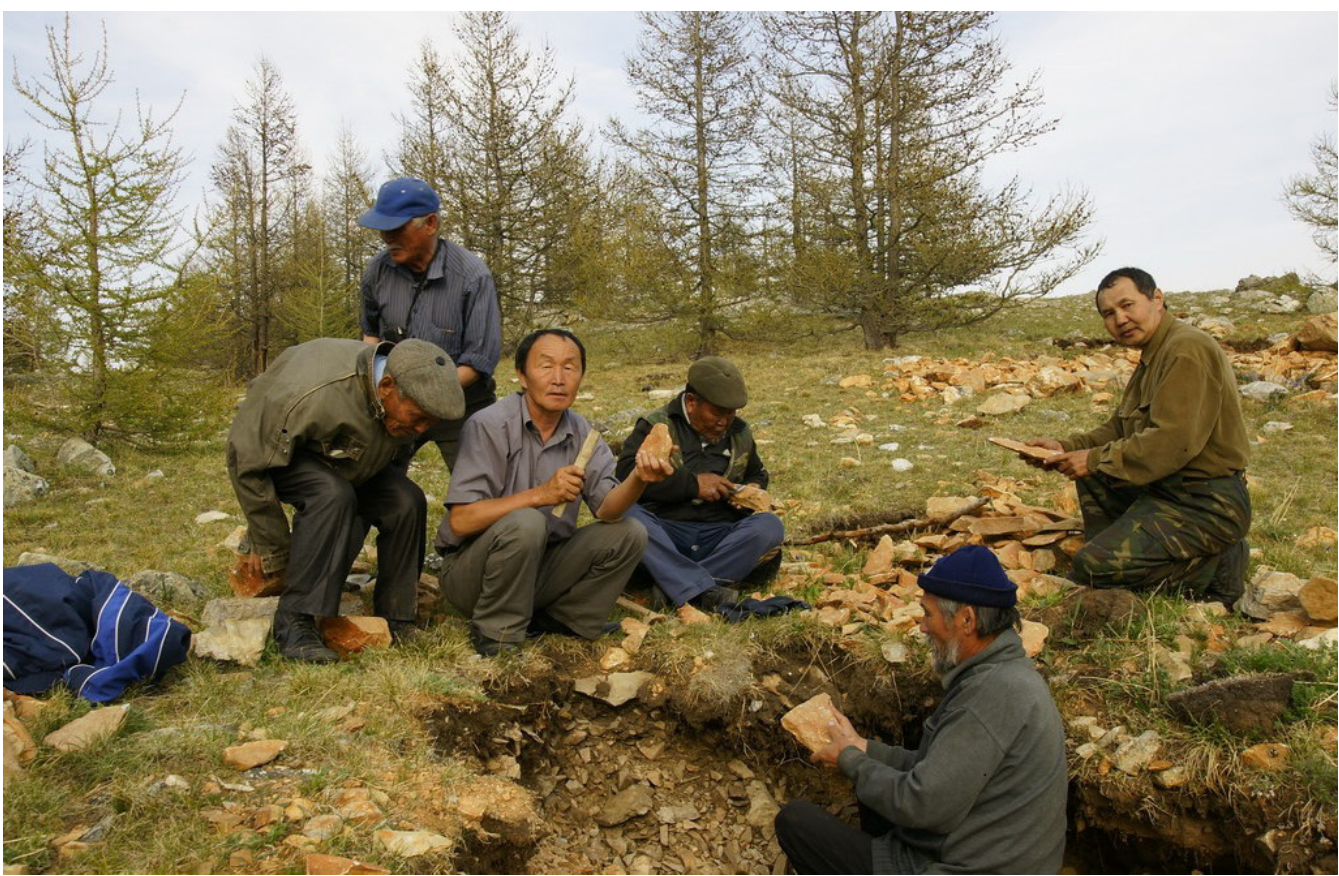

Фото 5. Мастера-камнерезы за отбором Чонар-Даш. Мастера, обнаружив у месторождения множество брошенных предыдущими недобросовестными копателями образцов камней, решили не копать новую яму-шурф, а подобрать камни. Стоит на заднем плане Д. Х. Дойбухаа; сидят слева направо: К. М. Саая, С. С. Бышкак,

К. Т. Хунан, С. Х. Кочаа, Х. Б. Донгак. Фото Шолбана Биче-оола, 2012 г.

Photo 5. Master stone cutters selecting pieces of Chonar-Dash. Having discovered a fresh pit with a heap of stone discarded by illegal miners, the professionals have decided to sort out the stones rather than dig a new pit. Standing in the background, D. H. Doibuhaa; seated, left to right, K.M. Saaya, S. S. Byshkak, K. T. Hunan, S. H. Kochaa, H. B. Dongak. Photo by Sholban Biche-Ool, 2012. 
После завершения работ проводилась специальная церемония выражения благодарности хозяевам священных Великих гор Бай-Тайги и горы Сарыг-Хая за подаренную возможность добыть Чонар-Даш. При этом еще раз произносили молитвы, по территории месторождения разбрасывались привезенные с собой дары (оставленные с первой церемонии получения разрешения на добычу Чонар-Даша), небольшое количество зерна, пшеницы или ржи, молока, топленого масла. Обычно здесь церемония была короткой, костер не разводился.

Поблагодарив хозяев Тайги, Неба и Земли, мастера аккуратно упаковывали в кожаные мешки - барба (вьючный мешок), таалын (вьючные мешки-корзинки для лошадей) добытые камни, загружали мешки на лошадей или на других вьючных животных (верблюдов, волов, сарлыков) и возвращались домой.

«Огбелеривистин бугу чагыг-чанчылдарын ургулчу сагып, оон иштинде бо Чонар-Дашты “Эгидип-шыгжаарын”шын кууседип чоруур болзувусса бо казарбайлакты ужулган черивис къаш даа чыл четпээнде база катап биеэги боду хевээр anaар, -салгалдар ажыглаар» («Если будем соблюдать все заведы предков, в том числе возврат-сохранение Чонар-Даша делать по традиционным правилам технологии «Эгидип-шыгжаары» правильно, то через год месторождение будет иметь такой же хороший вид и свойства, какие имел до раскопки, - для будущих потомков», - так говорил знаменитый камнерез Хертек Мижит-Доржу.

При этом с горечью и грустью он смотрел на огромные бледно-серые облака пыли, исходящие из высоких труб комбината «Туваасбест», расположенного у подножья гор, примерно в двадцати километрах и хорошо видимого с вершины горы Сарыг-Хая. Тогда нам молодым было не очень понятно, почему уважаемый Даай с такой грустью смотрит на знаменитый комбинат, которым он восхищался

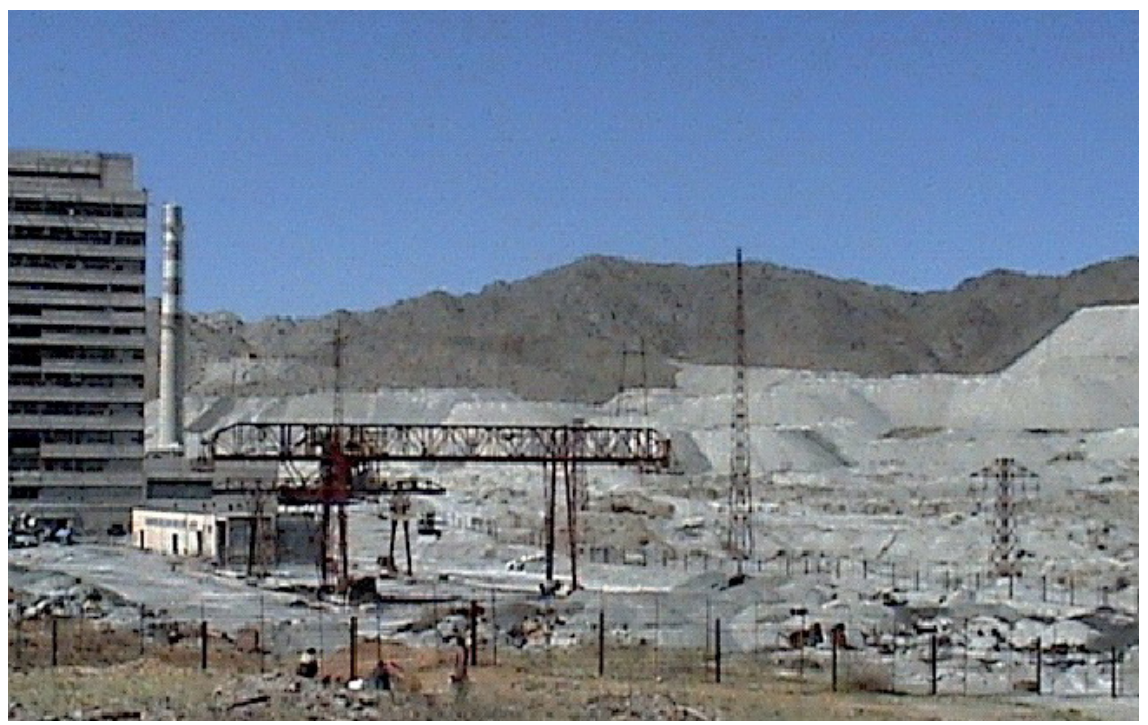

Фото 6. Техногенные отходы комбината «Туваасбест». Фото В. И. Лебедева, 2005 г.

Photo 6. Waste by TuvaAsbest industrial facility. Photo by V. I. Lebedev, 2005. 
совсем недавно. Говорил, что там наша молодежь зарабатывает хорошие деньги, счастливо живут. Благодаря строительству этого крупного горнодобывающего предприятия построен г. Ак-Довурак и прекрасная автодорога до Абакана.

Только потом, много лет спустя, когда бледно-серой пылью стали покрываться близлежащие долины реки Хемчик, горы превращались в белые техногенные отходы (фото 6), когда пошли разговоры о болезнях животных и людей из-за этой пыли, стало понятно почему мастербыл грустным.

Наши современники уже успели показать свое потребительское отношение к природным ресурсам, в том числе к месторождению «волшебного» камня Чонар-Даш. В нарушение тувинских традиций добычу камня производят в летнее время, когда земля находится в оттаявшем состоянии, и невозможно соблюдать правила уургай. И, как следствие -происходят обвалы земли в больших объемах, на глубине ям она смешивается с чистыми камнями ЧонарДаш, исключая возможность восстановления рудоносного слоя месторождения. Добытчики не производят обратной укладки камней в выкопанные ямы. Множество прекрасных образцов остаются брошенными на земле под открытым небом, портятся под палящим солнцем.

В результате, в настоящее время месторождение находится в плачевном состоянии (фото 7). Это вызывает справедливое возмущение старых, истинных народных мастеров-камнерезов.

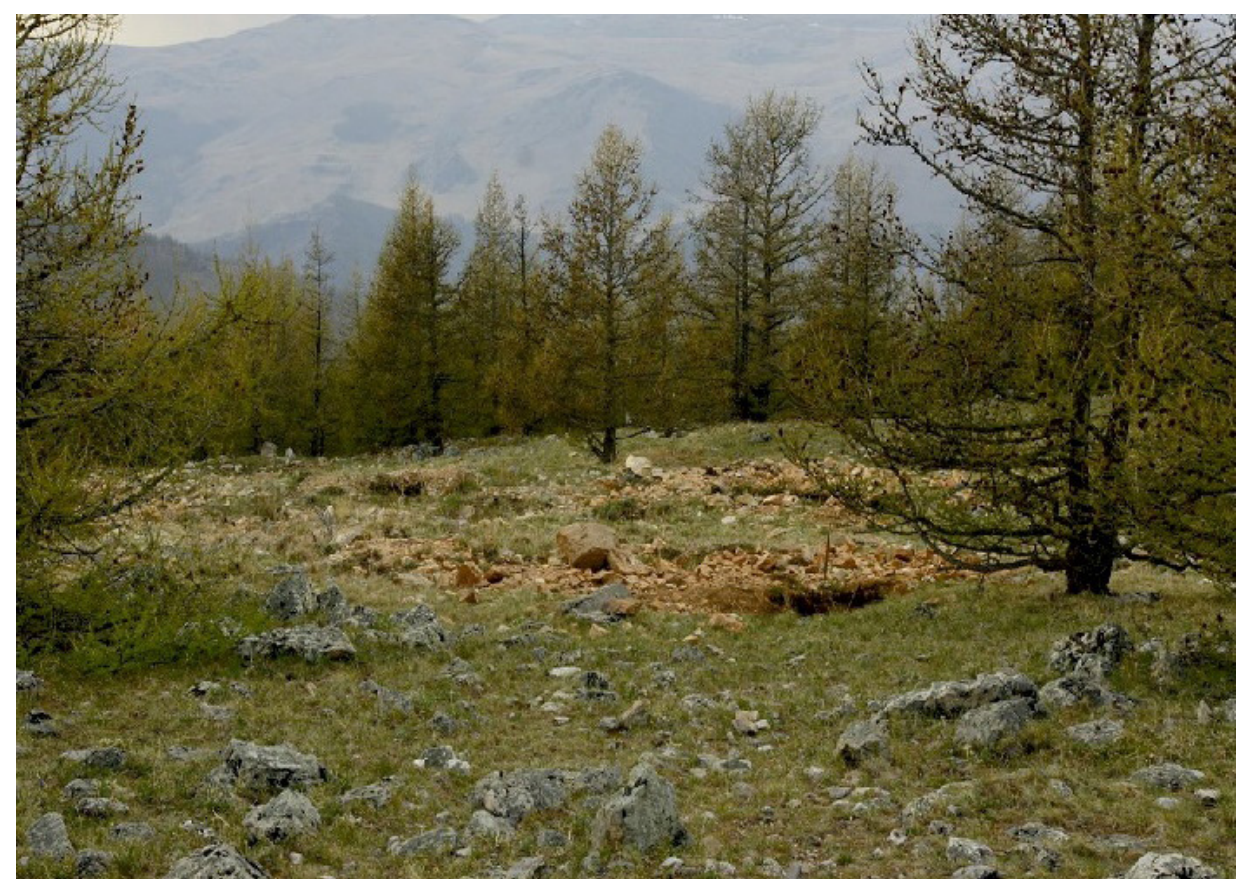

Фото 7. Сегодняшнее состояние месторождения Чонар-Даша на горе Сарыг-Хая в Бай-Тайгинском районе Республики Тыва. Из архива Национального музея им. Алдан-Маадыр РТ, г. Кызыл. 2015 г.

Photo 7. The current state of Chonar-Dash deposit on Mt. Saryg - Haya in Bay-Tanginski rayon, Republic of Tyva. From the archives of Aldan-Maadyr National Museum of Tuva, Kyzyl, 2015. 
Еще большее возмущение у местных жителей вызывают такие объекты современности как захоронения техногенных отходов комбината «Тувакобальт» в Чеди-Хольском районе; вскрытие главного рудного тела Тарданского месторождения в Каа-Хемском районе (фото 8); и другие объекты бывших и действующих крупных горнодобывающих промышленных предприятий.

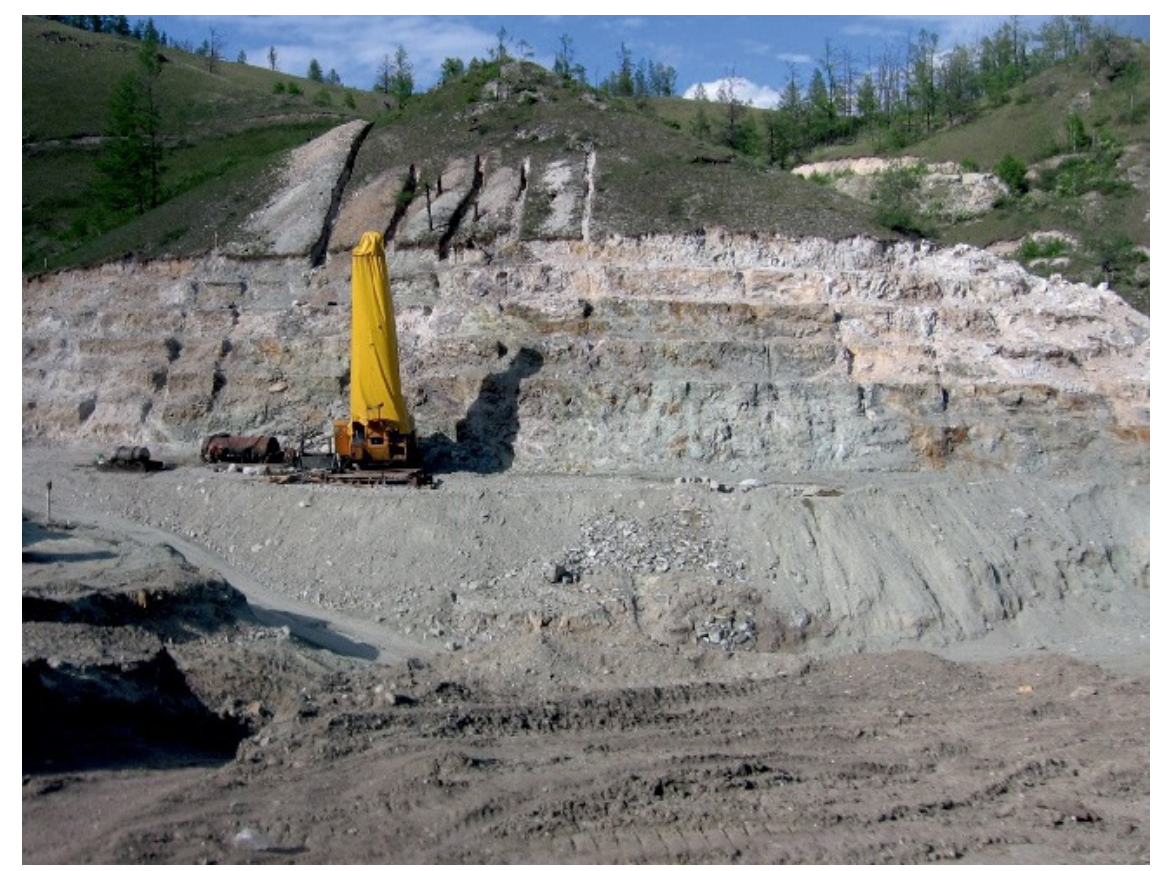

Фото 8. Вскрытие главного рудного тела Тарданского месторождения. Фото В. И. Лебедева, 2005 г.

Photo 8. Uncovering of the main ore body, Tardanskoye deposit. Photo by V. I. Lebedev, 2005.

Местные жители считают, что особую опасность для экологии также представляет Кызыл-Таштыгский горно-обогатительный комбинат китайской компании «Лунсин», находящийся в самых верховьях Енисея, и другие, вновь открываемые и предусматриваемые в стратегии развития республики крупные промышленные предприятия. Социологические опросы тоже показывают неоднозначное отношение населения к реализации проектов по созданию крупных промышленных предприятий необходимых для динамичного, инновационного развития региона, в том числе и для обеспечения занятости местного населения (Анайбан, Балакина, 2015).

Даже в отношении главного инфраструктурного, узлового проекта строительства железной дороги Кызыл-Курагино, которая призвана соединить Туву с Россией, имеются сомневающиеся и противники (Кан, 2010: Электр. ресурс). И население готово изменить свое отношение к строительству желез- 
ной дороги и освоению месторождений при решении ряда вопросов, главным из которых большинство (43,4 \% опрошенных) назвали сохранение культуры тувинцев, их языка, традиций и религии (там же).

В то же время нужно отметить, что в отношении некоторых новых крупных угледобывающих предприятий таких как «Межегейуголь», или «Улуг-Хем уголь» каких-либо негативных выступлений не замечено. Видимо, это связано с тем, что данные компании работают с применением новых технологий, которые не наносят большого вреда экологии. Как нам сказал в 2017 г. один из местных жителей: «Ында багай чуу деп, шаандагы ышкаш уургай казып ажылдап турар улуста» («Что там плохого, они же шахтным способом работают, как раньше»).

\section{Проблемы взяимосвязи традиционных технологий с экономическими задачами региона}

Правила обращения с окружающей природой тувинцев, которые воплощают особенности их экологической культуры, мы считаем, намного жестче требований современных экологических стандартов крупных промышленных предприятиях природопользования. Поэтому большинству коренных жителей одного из экологически чистых регионов России трудно принять все предлагаемые им нововведения, несмотря на искреннее желание зарабатывать деньги, улучшать благосостояние семьи и т.д. На этом противоречии базируются многие проблемы экономики республики. У коренного населения свои предпочтения в трудоустройстве, своя оценка крупных проектов природопользования (Кан, 2010: Электр. ресурс; Балакина, Калгыдай, 2015).

Поэтому современная наука должна работать над созданием таких новых технологий природопользования, в которых экологические требования (стандарты) должны быть не ниже, чем в традиционных технологиях. Необходимо проведение научных исследований и разработок направленных на поиск возможностей (способов) приведения современных технологий, в их экологической составляющей, в соответствие с требованиями традиционных технологий, чего и ожидают (требуют) коренные жители.

В настоящее время, значимость хозяйственных традиций, традиционных технологий, на взгляд автора, не стоит преуменьшать. По крайней мере, следует учитывать их устойчивость и преемственность. Важным в данном отношении представляется заключение А. К. Кужугет, которая подчеркивает, что тувинцы унаследовали от скифов, гуннов, тюрков, монголов сложнейшие техники обработки металлов - литье, ковку, резьбу по золоту, бронзе, железу (Кужугет, 2010: 16). Следует также обратить внимание на то, что в средневековой Туве большое развитие получили горное дело, металлургия и кузнечное ремесло. Кроме того, здесь добывали соль, каменный уголь, строительные материалы (камень, алебастр, гипс, глины) (История Тувы, 2001: 168). Здесь осваивали 
железную руду, медь, серебро, золото и олово (Кызласов, 1969: 46). Несомненно, благодаря этому среди тувинцев сохранился и тот тип работника, который способен к монотонному труду, хотя такой труд для тувинцев в целом и в настоящее время малопривлекателен (Балакина, Кылгыдай, 2015: 31).

Очередной этап освоения природных богатств Тувы - слаборазвитого, депрессивного, приграничного региона Южной Сибири, выдвигает ряд актуальных задач, связанных с адаптацией коренных жителей к условиям промышленного освоения региона, с одновременным обеспечением сохранения экологии. Речь идет о взаимосвязи этнопрактик и экономики, с вопросами адаптации населения и его понимания современных технологий.

Возникает противоречивая ситуация: с одной стороны региону нужны крупные бюджетообразующие промышленные предприятия, способные не только вывести республику из унизительной дотационности, но и обеспечить местное население рабочими местами и повысить уровень их жизни, а с другой стороны - среди жителей есть опасение, что эти же предприятия в очередной раз могут нанести непоправимый ущерб экологии региона, ее уникальной природе.

В настоящее время продолжается обсуждение как в официальных кругах, так и среди населения проекта Стратегии социально-экономического развития Республики Тыва на период до 2030 года, разработанного Министерством экономики РТ совместно с отраслевыми министерствами Правительства Республики Тыва. Стратегия, по мысли ее авторов, отражает специфику республики в экономическом пространстве России и направлена на реализацию ее основных конкурентных преимуществ. Проект Стратегии размещен для обсуждения и внесения предложений на сайте Правительства и Минэкономики Республики Тыва (Проект Стратегии ..., 2018: Электр. ресурс).

В данном документе стратегической целью социально-экономического развития Республики Тыва до 2030 г. названо обеспечение высокого качества жизни населения на основе создания условий для самодостаточного развития, стабилизации динамичных темпов экономического роста за счет повышения эффективности использования экономического потенциала.

Как считают геологи, в значительной степени перспективы социально-экономического развития региона определяют богатство и разнообразие видов полезных ископаемых Тувы, которые могут превратить его в регион с развитым горнопромышленным комплексом (Лебедев, Кужугет, 1998). Подтверждением этого является и то, что самое динамичное социально-экономическое развитие Республики Тыва в советский период (1944-1990 гг.) было достигнуто, в т. ч. благодаря освоению ее богатейших природных и минеральных ресурсов. За этот период также и численность населения выросла более чем в три раза, а объем промышленного производства - почти в 80 раз. Были созданы многочисленные промышленные предприятия, в т. ч. перерабатывающие природные ресурсы, 
и среди них первенцы индустрии Тувы - горно-обогатительные комбинаты «Туваасбест», «Тувакобальт» и другие крупные промышленные предприятия союзного значения.

Но некоторые запланированные крупные предприятия так и не были построены. Более того, даже запроектированные и начавшиеся строительством объекты промышленных предприятий, ориентированных на освоение природных ресурсов, так и остались незавершенными, а впоследствии были разукомплектованы или распроданы. В последствии произошло резкое сокращение (в разы) количества действующих промышленных предприятий, объемов выпускаемой продукции, количества рабочих месть, и общее снижение уровня жизни населения.

Данные обстоятельства порождают многочисленные вопросы, в т. ч. при разработке новых программ и стратегий развития республики. В чем причины развала таких нужных, необходимых для обеспечения высокого качества жизни населения предприятий? Почему все произошло именно таким образом? Не повторится ли подобное при реализации разрабатываемых стратегий и программ?

Во многих публикациях исследований ученых основными причинами тех событий называют неправильную плановую экономику Советского союза, демократизацию общества в 1990-е гг., недостаточность законодательноправовых условий при переходе на рыночную экономику, отсутствие необходимой инфраструктуры, сложное географическое положение республики, особенности национально-регионального менталитета, тяжелые рельефные и климатические условия региона и т. д. и т. п. (Анайбан, Балакина, 2015; Балакина, 2012; Дабиев, Ягольницер, 2012; Ламажаа, 2011; Лебедев, 2012; Лебедев, 2017; Ооржак, 2017 и др.). Все это конечно правильные, обоснованные выводы, которые необходимо учесть при дальнейшей работе над проектами стратегий и программ развития отраслей экономики республики.

Но, на взгляд автора, необходимо также учесть еще один немаловажный фактор - специфику особенностей традиционной экономической культуры, своеобразие природосообразности, ментальности психоэкологического воспитания проживающих на территории республики народов. Именно эта специфика и особенности стали основанием для недовольства и выступлений населения против индустриализации региона в «лихие» 1990-е годы, оказали существенное влияние на реализацию вышеперечисленных проектов, программ и стратегий.

\section{Заключение}

Добыча поделочного камня Чонар-Даш (агальматолита) тувинцами, являясь всего лишь начальным этапом хозяйственной деятельности внутри 
одного из видов народных художественных промыслов - камнерезного искусства, представляется нам интереснейшим явлением тувинской культуры. В самой технологии, которую мы описали в работе, отражаются высокие экологические требования тувинцев к самой человеческой деятельности, которые, очевидно, намного выше требований современных экологических стандартов промышленных предприятий природопользования. И эти требования позволяют не просто пользоваться природными ресурсами, но и пользоваться так, чтобы они не истощались, не подвергали экологию рискам. Поэтому при формировании стратегий и разработках программ динамичного развития региона необходима дополнительная экспертиза на соответствие экономических проектов нормам экологической культуры коренного населения.

\section{Благодарности}

Выражаю признательность всем организациям, коллегам, ученым, специалистам и народным мастерам-камнерезам, которые мне помогали (оказывали содействие) в разные годы при проведении данных исследований: Национальному музею имени Алдан-Маадыр Республики Тыва, в том числе заведующему отделом искуства, культуры и религии, заслуженному деятелю культуры Республики Тыва, заслуженному работнику культуры РФ А. С. Хертеку; народным мастерам-камнерезам; заслуженному художнику РФ К. Т. Хунан (1947-2018), лауреату Государственной премии РФ им. И. Е. Репина Х. К. Тойбухаа (1917-1981), народному мастеру М-Д. С. Хертек (1915-1973), лауреату Государственной премии РФ им. И. Е. Репина К. М. Саая, народному художнику РФ Д. Х. Дойбухаа, заслуженному деятелю искусств Республики Тыва В.Ш.Салчаку и др.; коллегам - ученым и специалистам ТувИКОПР СО РАН: докт. геол.-мин.наук. В. И. Лебедеву, Н. И. Лебедеву, докт. экон. наук Г. Ф. Балакиной, канд. экон. наук Д. Ф. Дабиеву, Ю. В. Самбыла, А. М. Сат, Л. А. Непомнящей и др.

\section{СПИСОК ЛИТЕРАТУРЫ}

Анайбан, 3. В., Балакина, Г. Ф. (2015) Динамика межэтнических отношений и этнических стереотипов в Республике Тыва // Социологические исследования. № 8 (376). С. 93-99.

Балакина, Г. Ф. (2012) Депрессивные регионы: формирование стратегий со-циальноэкономического развития / отв. ред. Е. Б. Кибалов. Кызыл : ТувИКОПР СО РАН. 218 с.

Балакина, Г. Ф., Кылгыдай, А. Ч. (2015) Этнорегиональные модели адаптации к рынку труда в Туве / отв. ред. Л. В. Корель. Кызыл : ТувИКОПР СО РАН. 160 с.

Будегечи, Т. Б. (1995) Художественное наследие тувинцев: Судьбы искусств. Жизнь традиции. Диалог культур. От традиционного к современному. М.: Внешторгиздат. $152 \mathrm{c}$. 
Вайнштейн, С. И. (1974) История народного искусства Тувы. М.: Наука. 224 с.

Дабиев, Д. Ф., Ягольницер, М. А. (2012) Экономическая оценка эффективности освоения минеральных ресурсов Тувы / отв. ред. В. И. Лебедев. Кызыл : ТувИКОПР СО РАН. $130 \mathrm{c.}$

Демин, В. Ф., Ланзы, С. К., Кузнецов, И. Я. (1969) Оживший камень: Фотоальбом тувинской народной резьбы по камню.Кызыл: Тув. кн. изд-во.78 с.

История Тувы : в 2 т. (2001) / под общ. ред. С. И. Вайнштейна, М. Х. Маннай-оола. Новосибирск : Наука. Т. І. 367 с.

Кан, В. С. (2010) Чего ждут от строительства железной дороги и освоения месторождений жители Тувы (по материалам социологических исследований 2008-2010 гг. [Электронный ресурс] // Новые исследования Тувы. № 4. URL: https://nit.tuva.asia/nit/ article/view/477 (дата обращения: 15.02.2018).

Кореняко, В. А. (2002) Искусство народов Центральной Азии и звериный стиль. Серия: Культура народов Востока.М.: Восточная литература.327 с.

Кужугет, А. К. (2010) Художественные традиции тувинцев // Вестник Тывинского государственного университета. Вып. 1: Социальные и гуманитарные науки. № 1. C. $14-22$.

Кухта, М. С., Ооржак, В. О. (2014) Традиционные технологии художественной обработки чонар-даша // Дизайн. Теория и практика. № 16. С. 80-89.

Кызласов, Л. Р. (1969) История Тувы в средние века. М. : Изд-во МГУ. 214 с.

Ламажаа, Ч. К. (2011) Тува между прошлым и будущим. 2-е изд. СПб.: Алетейя. 368 с.

Лебедев, В.И. (2017) Освоение минерально-сырьевой базы Республики Тыва // Региональная экономика: технологии, экономика, экология и инфраструктура: Материалы 2-й Междунар. науч.-практ. конф. (18-20.10.2017, Кызыл, Россия) / отв. ред. Г. Ф. Балакина. Кызыл: ТувИКОПР СО РАН. 388 с. С. 199-212.

Лебедев, В. И., Кужугет, К. С. (1998) Минерально-сырьевой потенциал Республики Тыва: возможности его использования в 1999-2001 гг. и перспективы дальнейшего освоения. Кызыл : ТувИКОПР СО РАН. 35 с.

Лебедев, Н.И. (2012) Минеральные ресурсы Тувы: обзор и анализ полезных ископаемых / отв. ред. В. И. Лебедев. Кызыл : ТувИКОПР СО РАН. 284 с.

Монгуш, Ч. Х. (2017) Технологии изготовления традиционных женских украшений тувинцев // Новая наука: Теоретический и практический взгляд. Т. 2. № 3. С. 203-207.

Ондар, А. Б., Бадыргы, А. Ш. (2015) Тувинская национальная одежда «чени-чок» // Инновационная наука. № 10-3. С. 226-227.

Ондар,А.Б. (2017) Тувинский народный костюм: проблемы изучения в пространстве музея // Человек и культура. № 6. С. 1-6.

Ооржак, В.О. (2015) Экологические особенности традиционных способов добычи чонар-даша // Региональная экономика: технологии, экономика, экология и инфраструктура: Материалы Междунар. науч.-практ. конф. (14-16.10.2017, Кызыл, Россия) / отв. ред. Г. Ф. Балакина. Кызыл : ТувИКОПР СО РАН. 324 с. С. 272-279.

Ооржак, В.О. (2017) Проблемы и перспективы промышленного производства Тывы // ЭКО. № 2 (512). С. 121-133. 
Ооржак, В. О., Ондар, К. А. (2012) Технология изготовления традиционного музыкального инструмента игила : учеб.-метод. пособие для специальности 050502 «Технология и предпринимательство». Кызыл : ТувГУ. 97 с.

Ооржак, У. С., Сайбу, А. А. (2013) Биохимический состав традиционной пищи «далган» // Вестник Тувинского государственного университета. Вып. 2: Естественные и сельскохозяйственные наук. № 2 (17). С. 124-127.

Оюн, А. Б.-С. (2012) Особенности убоя овец и коз по традиционной технологии тувинцев // Вестник Тувинского государственного университета. Вып. 2: Естественные и сельскохозяйственные наук. № 2 (13). С. 89-92.

Проект стратегии социально-экономического развития Республики Тыва до 2030 года (2018) [Электронный ресурс] // Министерство экономики Республики Тыва. URL: http://www.mert.tuva.ru/directions/socio-economic-development/project_strategy_2030.html (дата обращения: 05.03.2018).

Червонная, С. М. (1995) Художники Республики Тыва. СПб.: Художники России. $184 \mathrm{c}$.

Эренчин, А. В., Сат, О. С., Ондар, А. А. (2018) Войлоковаляние у тувинцев: традиции и современность // Единство и идентичность науки: проблемы и пути решения : сб. ст. по итогам Междунар. науч.-практ. конф. (08.02.2018, Тюмень) : в 2 ч. / отв. ред. А. А. Сукиасян. Уфа : ООО Агентство международных исследований. Ч. 2. 271 с. С. 206-209.

Дата поступления: 12.09.2018 г.

\section{REFERENCES}

Anaiban, Z. V. and Balakina, G. F. (2015) Dinamika mezhetnicheskii otnoshenii i etnicheskikh stereotipov v Respublike Tyva [Dynamics of interethnic relations and ethnic stereotypes in the Republic of Tuva]. Sotsiologicheskie issledovaniia, no. 8, pp. 93-99. (In Russ.)

Balakina, G. F. (2012) Depressivnye regiony: formirovanie strategii sotsial'no-ekonomicheskogo razvitiia [Economically depressed regions: the formation of socio-economic development strategies] / ed. by E. B. Kibalov. Kyzyl, TuvIKOPR SO RAN. 218 p. (In Russ.).

Balakina, G. F. and Kylgydai, A. Ch. (2015) Etnoregional'nye modeli adaptatsii k rynku truda $v$ Tuve [Ethno-regional models of adaptation to the labour market in Tuva]. Kyzyl, TuvIKOPR SO RAN. 160 p. (In Russ.).

Budegechi, T. B. (1995) Khudozhestvennoe nasledie tuvintsev [The artistic heritage of Tuvans]. Moscow, s. n. 151 p. (In Russ.).

Vainshtein, S. I. (1973) Istoriia narodnogo iskusstva Tuvy [History of folk art in Tuva]. Moscow, Nauka. 223 p. (In Russ.).

Dabiev, D. F. and Iagol'nitser, M. A. (2012) Ekonomicheskaia otsenka effektivnosti osvoeniia mineral'nykh resursov Tuvy [An economic evaluation of the effectiveness of the development of mineral resources of Tuva] / ed. by V. I. Lebedev. Kyzyl, TuvIKOPR SO RAN. 130 p. (In Russ.).

Demin, V. F., Lanzy, S. K. and Kuznetsov, I. Ia. (1969) Ozhivshii kamen' [Stone comes to life] : A photo album of Tuvan folk stone carving. Kyzyl, Tuvan book publisher. 78 p. (In Russ.). 
Istoriia Tuvy [The History Of Tuva] (2001) : in 2 vol. 2nd ed / ed. by S. I. Vanshtein and M. Kh. Mannai-ool. Novosibirsk, Nauka. Vol. I. 367 p. (In Russ.).

Kan, V. S. (2010) Chego zhdut ot stroitel'stva zheleznoi dorogi i osvoeniia mestorozhdenii zhiteli Tuvy (po materialam sotsiologicheskikh issledovanii 2008-2010 gg. [What people of Tuva expect from the construction of a railway and the use of mineral deposits (from the sociological surveys of 2008-2010)]. The New Research of Tuva, no. 4 [online] Available at: https://nit.tuva.asia/nit/article/view/477 (access date: 15.02.2018). (In Russ).

Koreniako, V. A. (2002) Iskusstvo narodov Tsentral'noi Azii i zverinyi stil'. Seriia: Kul'tura narodov Vostoka [The art of the peoples of Central Asia and the animal style. Series: Cultures of the East]. Moscow, Vostochnaia literatura Publ. 327 p. (In Russ.).

Kuzhuget, A. K. (2010) Khudozhestvennye traditsii tuvintsev [Artistic traditions of Tuvans]. Vestnik Tyvinskogo gosudarstvennogo universiteta. Vol. 1: Sotsial'nye i gumanitarnye nauki, no. 1, pp. 14-22. (In Russ.).

Kukhta, M. S. and Oorzhak, V. O. (2014) Traditsionnye tekhnologii khudozhestvennoi obrabotki chonar-dasha [Traditional technologies of Chonar-Dash cutting]. Dizain. Teoriia $i$ praktika, no. 16, pp. 80-89. (In Russ.).

Kyzlasov, L. R. (1969) Istoriia Tuvy v srednie veka [The History of Tuva in the Middle Ages]. Moscow, MGU Publ. 214 p. (In Russ.).

Lamazhaa, Ch. K. (2011) Tuva mezhdu proshlym i budushchim [Tuva between the Past and the Future]. 2nd ed. St. Petersburg, Aleteiia. 368 p. (In Russ.).

Lebedev, V. I. (2017) Osvoenie mineral'no-syr'evoi bazy Respubliki Tyva [Development of mineral resources base of the Republic of Tyva]. In: Regional'naia ekonomika: tekhnologii, ekonomika, ekologiia i infrastruktura [Regional economy: technologies, economy, ecology and infrastructure]: Materials of the 2nd International research and practical conference (18-20.10.2017, Kyzyl, Russia) / ed. by G. F. Balakina. Kyzyl, TuvIKOPR SO RAN. 388 p. Pp. 199-212. (In Russ.).

Lebedev, V. I. and Kuzhuget, K. S. (1998) Mineral'no-syr'evoi potentsial Respubliki Tyva: vozmozhnosti ego ispol'zovaniia $v 1999-2001 \mathrm{gg}$. i perspektivy dal'neishego osvoeniia [Mineral resource potential of the Republic of Tuva: the prospects of its use in 1999-2001 and further development]. Kyzyl, TuvIKOPR SO RAN. 35 p. (In Russ.).

Lebedev, N. I. (2012) Mineral'nye resursy Tuvy: obzor i analiz poleznykh iskopaemykh [Mineral resources of Tuva: a review and analysis] / ed. by V. I. Lebedev. Kyzyl, TuvIKOPR SO RAN. 284 p. (In Russ.)

Mongush, Ch. Kh. (2017) Tekhnologii izgotovleniia traditsionnykh zhenskikh ukrashenii tuvintsev [Manufacturing techniques of traditional women's jewelry of Tuvans]. Novaia nauka: Teoreticheskii i prakticheskii vzgliad, vol. 2, o. 3, pp. 203-207. (In Russ.).

Ondar, A. B. and Badyrgy, A. Sh. (2015) Tuvinskaia natsional'naia odezhda «chenichok» [Cheni-Chok, a piece of Tuvan national costume]. Innovatsionnaia nauka, no. 10-3, pp. 226-227. (In Russ.).

Ondar, A. B. (2017) Tuvinskii narodnyi kostium: problemy izucheniia v prostranstve muzeia [Tuvan folk costume: problems of studying in the museum space]. Chelovek $i$ kul'tura, no. 6, pp. 1-6. (In Russ.). 
Oorzhak, V. O. (2015) Ekologicheskie osobennosti traditsionnykh sposobov dobychi chonar-dasha [Environmental features of traditional methods of Chonar-Dash extraction]. In: Regional'naia ekonomika: tekhnologii, ekonomika, ekologiia i infrastruktura [Regional economy: technologies, economy, ecology and infrastructure]: Materials of the 2nd International research and practical conference (18-20.10.2017, Kyzyl, Russia) / ed. by G. F. Balakina. Kyzyl, TuvIKOPR SO RAN. 388 p. Pp. 272-279. (In Russ.).

Oorzhak, V. O. (2017) Problemy i perspektivy promyshlennogo proizvodstva Tyvy [Problems and prospects of industrial production in Tuva]. EKO, no. 2 (512), pp. 121-133. (In Russ.).

Oorzhak, V. O. and Ondar, K. A. (2012) Tekhnologiia izgotovleniia traditsionnogo muzykal'nogo instrumenta igila [Igil, a traditional musical instrument: technology of production] : an educational and methodical manual for major 050502 "Technology and entrepreneurship". Kyzyl, TuvGU. 97 p. (In Russ.).

Oorzhak, U. S. and Saibu, A. A. (2013) Biokhimicheskii sostav traditsionnoi pishchi «dalgan» [Biochemical composition of traditional food «dalgan»]. Vestnik Tuvinskogo gosudarstvennogo universiteta, vol. 2: Estestvennye i sel'skokhoziaistvennye nauk, no. 2 (17), pp. 124-127. (In Russ.).

Oiun, A. B.-S. (2012) Osobennosti uboia ovets i koz po traditsionnoi tekhnologii tuvintsev [Traditional Tuvan techniques of slaughtering sheep and goats]. Vestnik Tuvinskogo gosudarstvennogo universiteta, vol. 2: Estestvennye i sel'skokhoziaistvennye nauki, no. 2 (13), pp. 89-92. (In Russ.).

Proekt strategii sotsial'no-ekonomicheskogo razvitiia Respubliki Tyva do 2030 goda [Draft strategy of socio-economic development of the Republic of Tuva until 2030] (2018). Ministerstvo ekonomiki Respubliki Tyva [online] Available at: http://www.mert.tuva.ru/directions/socio-economic-development/project_strategy_2030.html (access date: 05.03.2018). (In Russ.).

Chervonnaia, S. M. (1995) Khudozhniki Respubliki Tyva [Painters of The Republic of Tuva]. St. Petersburg, Khudozhniki Rossii. 184 p. (In Russ.).

Erenchin, A. V., Sat, O. S. and Ondar, A. A. (2018) Voilokovalianie u tuvintsev: traditsii i sovremennost' [Felting in Tuva: tradition and modernity]. In: Edinstvo i identichnost' nauki: problemy i puti resheniia [Unity and identity of science: problems and solutions] : collection of articles on the results of the International scientific practical conference (08.02.2018, Tyumen) : in 2 vol. / ed. by A. A. Sukiasian. Ufa, OOO Agentstvo mezhdunarodnykh issledovanii. Vol. 2. 271 p. Pp. 206-209. (In Russ.).

Submission date: 12.09 .2018 .

\section{Для цитирования:}

Ооржак В. О. Добыча Чонар-Даша: традиционная технология и элемент экологической культуры тувинцев [Электронный ресурс] // Новые исследования Тувы. 2018, № 4. URL: https://nit.tuva.asia/nit/article/view/815 (дата обращения: дд.мм.гг.). DOI: 10.25178/ nit.2018.4.12

\section{For citation:}

Oorzhak V. O. The Extraction of Chonar-Dash: traditional technology and a part of Tuvan environmental culture. The New Research of Tuva, 2018, no. 4 [on-line] Available at: https://nit. tuva.asia/nit/article/view/815 (accessed: ...). DOI: 10.25178/nit.2018.4.12 